\title{
Cichotyboside, A Sesquiterpene Glycoside from Cichorium intybus Attenuates Carbon Tetrachloride-Induced Liver Injury in Rat
}

\author{
Chandra Shekar Singh ${ }^{1}$, Papiya Bigoniya ${ }^{2, *}$ \\ ${ }^{1}$ Kamla Nehru Institute of Management and Technology, Faculty of Pharmacy, Sultanpur, 228001, U.P., India \\ ${ }^{2}$ DSKM College of Pharmacy, RKDF University, Airport Bypass Road, Gandhinagar, Bhopal, 462033, M.P., India
}

Received June 24, 2021; Revised August 14, 2021; Accepted November 22, 2021

\section{Cite This Paper in the following Citation Styles}

(a): [1] Chandra Shekar Singh, Papiya Bigoniya , "Cichotyboside, A Sesquiterpene Glycoside from Cichorium intybus Attenuates Carbon Tetrachloride-Induced Liver Injury in Rat," Advances in Pharmacology and Pharmacy, Vol. 10, No. 1, pp. 18 - 34, 2022. DOI: 10.13189/app.2022.100103.

(b): Chandra Shekar Singh, Papiya Bigoniya (2022). Cichotyboside, A Sesquiterpene Glycoside from Cichorium intybus Attenuates Carbon Tetrachloride-Induced Liver Injury in Rat. Advances in Pharmacology and Pharmacy, 10(1), 18 - 34. DOI: 10.13189/app.2022.100103

Copyright $(\mathrm{O} 2022$ by authors, all rights reserved. Authors agree that this article remains permanently open access under the terms of the Creative Commons Attribution License 4.0 International License

\begin{abstract}
Aims: Cichorium intybus L. is traditionally used for the management of the various liver disorders and also widely scientifically reported for hepatoprotection. The present study aims at investigating cichotyboside, bioactive sesquiterpene glycoside, from seeds for hepatoprotective effect against carbon tetrachloride $\left(\mathrm{CCl}_{4}\right)$ following isolation and characterization. Methods: Cichotyboside was isolated from $C$. intybus seeds and characterized by infrared spectroscopy (IR), liquid chromatography-mass spectrometry (LC/MS), and carbon 13 nuclear magnetic resonance $\left({ }^{13} \mathrm{C}\right.$ NMR $)$. High-performance liquid chromatography (HPLC) and high-performance thin-layer chromatography (HPTLC) have been developed for the standardization of Cichotyboside. In this study, biochemical assays, liver functional capacity restoration regarding drug metabolism, antioxidant potential, and histological staining were applied to evaluate the anti-hepatotoxic efficacy of cichotyboside on a carbon tetrachloride induced liver injury in rats. Results: The results showed that cichotyboside could significantly attenuate the pathological changes, increase the levels of hepatocyte repair, and regulate oxidative damage. Hepatoprotective activity of cichotyboside is indicated by its ability to decrease thiopental induced sleeping time, increased BSP clearance, reverse effect of $\mathrm{CCl}_{4}$ on the body weight, relative liver weight, serum liver function parameters,
\end{abstract}

histopathology and activity of liver antioxidant enzymes. Conclusion: Cichotyboside exerts hepatoprotective activity against the $\mathrm{CCl}_{4}$ induced toxicity, possibly by its remarkable antioxidant potential, reversing the impaired metabolisms and repairing the fatty changes in hepatocytes.

Keywords Carbon Tetrachloride, Cichorium intybus, Cichotyboside, Hepatoprotective, Sesquiterpene Glycoside

\section{Introduction}

Cichorium intybus L. commonly known as chicory and kasani belongs to family Asteraceae. It is a woody, erect, and perennial herbaceous plant with a fleshy taproot. $C$. intybus has been reported to possess great medicinal importance because of its marvelous phytochemical composition. C. intybus is useful in treating dysmenorrhoea, insomnia, splenitis, obesity, hyperlipidemia, and tachycardia [1,2]. It also possesses antiulcerogenic, anti-inflammatory, and diuretic activity [3]. Leaves and roots of C. intybus have strong nematicidal and antibacterial activities [4].

Liv-52 syrup, one of the bestselling liver tonics in India, is manufactured by Himalaya Healthcare Ltd. Jigreen, 
manufactured by Hamdard Laboratories is a Unani polyherbal liver medication having a high market reputation. Both these formulations contain kasani as a major ingredient. Dabur research foundation has been granted with a patent for hepatoprotective composition claiming treatment of hepatitis $\mathrm{B}$ and $\mathrm{E}$ infection containing kasani [5]. C. intybus is used in biliary disorders like jaundice and is an ingredient of several recipes prescribed by traditional healers to cure hepato-biliary complaints [6].

The ethnobotanical studies have reported the use of leaves in curing jaundice, liver disorders, vomiting, loose motion, fever, and pleurisy [7]. Madani et al. have reported protective effects of Silybum marianum and $C$. intybus polyphenolic extracts on thioacetamide induced hepatotoxicity in rats [8]. A decoction of the whole plant of $C$. intybus is used for the treatment of jaundice and hepatitis in Pakistan [9]. Methanolic extract of C. intybus whole plant has shown hepatoprotective activity against acetaminophen induced liver damage [10]. C. intybus showed a protective effect against oxytetracycline induced fatty liver in rats [11]. Methanol extracts of C. intybus, in combination with ginger, significantly restored the carbon tetrachloride-induced $\left(\mathrm{CCl}_{4}\right)$ hepatotoxicity in rats [12]. Different extracts of $C$. intybus dried herb showed hepatoprotective activity against $\mathrm{CCl}_{4}$ intoxication $[13,14]$ Hepatoprotective effect of $C$. intybus leaf extracts was reported on $\mathrm{CCl}_{4}$ induced liver damage in rats $[15,16]$. Alcoholic extract $C$. intybus seed showed protection against acetaminophen and $\mathrm{CCl}_{4}$ induced hepatic damage in rats $[17,18]$. C. intybus root and root callus extract showed a protective effect on the morphofunctional state of the liver in rats with $\mathrm{CCl}_{4}$ induced hepatitis [19-21].

The hepatoprotective effect of $C$. intybus is reported on the whole herb, leaf, seed, and root extracts. C. intybus contains a number of phytocompounds such as inulin, sesquiterpene lactones, glycoside, coumarins, vitamins, sterols, flavonoids, and tannins $[12,22,23]$. Esculetin, a phenolic compound found in $C$. intybus have a protective effect against paracetamol and $\mathrm{CCl}_{4}$ induced hepatic damage [24]. Zhang et al. reported in vitro hepatocytoprotective and anti-hepatitis B virus properties of cichoric acid from C. intybus leaves [25].

The seed of $C$. intybus afforded a sesquiterpene glycoside, cichotyboside that exhibited anti-hepatotoxic activity against $\mathrm{CCl}_{4}$ induced toxicity by reducing serum glutamate oxaloacetic transaminase (SGOT) and serum glutamate pyruvic transaminase (SGPT) and alkaline phosphatage (ALP) level. This sesquiterpene glycoside was isolated from the methanolic extract of the $C$. intybus seeds, which has been characterized as cichotyboside $\{2 \alpha, 6 \beta, 7 \beta, 15$-tetrahydroxy-1(10),4(5)-diene-guaian- $9 \alpha, 12$ -olide-7-O- $\beta$-caffoyl-15-O- $\beta$-D-glucoside $\} \quad[26]$. The present study attempts isolation of cichotyboside from $C$. intybus seeds followed by characterization and authentication with the aid of high performance liquid chromatograph (HPLC), liquid chromatography-mass spectrometry (LC/MS), and high performance thin layer chromatograph (HPTLC) techniques. Characterization of cichotyboside by HPLC, LC/MS and HPTLC was attempted for the first time to authenticate as reference standard. Hepatoprotective and antioxidant potential of cichotyboside was explored against $\mathrm{CCl}_{4}$ induced hepatotoxicity. Estimation of liver metabolizing efficiency as a measure of thiopental induced sleeping time, and bromsulphthalein (BSP) clearance, liver function biochemical parameters, free radical scavenging ability, and histopathological changes in liver tissues was performed in order to ascertain the whole spectrum of the hepatoprotective potential of cichotyboside.

\section{Materials and Methods}

\subsection{Drugs and Chemicals}

Bromsulphalein was procured from HiMedia Lab. Ltd., Mumbai, and thiopental was obtained as a gift sample from Neon Lab., Mumbai.

\subsection{Plant Material}

The seeds of $C$. intybus were collected from the local market of Bhopal, M.P., India. The seeds were identified by Dr. H. B. Singh, Scientist F, and Head, Raw Material Herbarium and Museum, NISCAIR, New Delhi, India. A voucher specimen (NISCAIR/RHMD/Consult/-2009-10/1 234/47) of the seed has been retained in the department for reference purposes.

\subsection{Isolation of Cichotyboside from $C$. intybus}

Dry, coarse powder of $C$. intybus seed was extracted with absolute ethanol following the cold percolation method. The filtrate was concentrated to a small volume under reduced pressure using a rotary vacuum evaporator. The crude extract (yield 14.23\%) was then fractionated into petroleum ether, chloroform, and methanol soluble fractions having yields $0.94,1.12$, and $7.45 \%$, respectively. The methanol soluble fraction was subjected to a qualitative test for the presence/absence of phenolic compounds. The methanol fraction was chromatographed on Merck silica gel $60 \mathrm{~F}_{254}$ plates. On the basis of literature search, solvent system petroleum ether: benzene: methanol was used in increasing order of polarity in order to achieve the maximum possible compounds with better separation [26]. Molish's reagent was used for the detection of spots. The 1:3:2 ratio of petroleum ether: benzene: methanol showed two well separated with $R_{f}$ value 0.13 and 0.42 .

\subsection{Column Chromatography}

Phytoconstituents present in methanol fraction were 
separated by column chromatography. A column of 760 $\mathrm{mm}$ height, $120 \mathrm{~mm}$ diameter, was packed up to a height of $550 \mathrm{~mm}$ with a slurry of silica gel-60 (particle size 40-63 $\mu \mathrm{m})$ in 1:3:2 ratio of petroleum ether: benzene: methanol. The methanol fraction $(50 \mathrm{gm})$ was loaded on to the column, eluted with a fixed combination of 1:3:2 ratio of petroleum ether: benzene: methanol in a flow rate of $1 \mathrm{ml} / \mathrm{min}$. The samples were collected as $10 \mathrm{ml}$ elutes and simultaneously chromatographed in 1:3:2 ratio of petroleum ether: benzene: methanol. The vials 33-59 showed a single spot $\left(\mathrm{R}_{\mathrm{f}} 0.42\right)$ and labeled as fraction $\mathrm{C}$ and subjected to HPLC, LC/MS, IR, ${ }^{13} \mathrm{C}$ NMR, and HPTLC analysis for identification and characterization. The dry weight of fraction $\mathrm{C}$ was found to be $9.44 \mathrm{gm}$, with a yield of $0.47 \%$.

\subsection{HPLC Analysis of Fraction C}

The chromatographic analysis was performed on the Shimadzu LC-20AD liquid chromatography system, equipped with CAT-228-39001-38 pump, 228-393000-38 photodiode array detector working in the range $190-800$ $\mathrm{nm}$, a quaternary solvent delivery system, and a rheodyne injection valve fitted with a $20 \mu \mathrm{l}$ injection loop. The data were recorded and processed with the LC solution integrated software. Baseline resolution of fraction $\mathrm{C}$ was obtained at $25 \pm 2^{\circ} \mathrm{C}$ using stainless steel Luna column $(150 \mathrm{~mm} \times 4.6 \mathrm{~mm})$, packed with octadecylsilane bonded to porous silica $(5 \mu \mathrm{m})$. An isocratic solvent system consisting of methanol: water in the ratio of 80:20 (v/v) was used. The mobile phase was passed through a 0.45 PVDF filter and degassed before use. The flow rate was kept constant at $1 \mathrm{ml} / \mathrm{min}$, and effluents were monitored at $254 \mathrm{~nm}$. Fraction C showed a prominent peak in HPLC chromatogram named peak C. Sample was dissolved in methanol, filtered through a $0.45 \mu \mathrm{m}$ membrane filter, and $20 \mu \mathrm{l}$ of the sample was injected.

\subsection{LC/MS Analysis of Fraction C}

LC/MS analysis was performed at ambient temperature $\left(22-24^{\circ} \mathrm{C}\right)$ using Varian Inc, USA equipped with the Prostar Binary LC with 500 MS IT PDA detectors and Polaris 5-C18-50 mm $\times 2.0 \mathrm{~mm}$ column. A binary isocratic solvent system consisting of methanol and $0.1 \%$ formic acid in water in a ratio of 80:20 (v/v) was used. The flow rate was $0.2 \mathrm{ml} / \mathrm{min}$. The operational parameters were of direct infusion mass type with ESI and APCI negative and positive mode ionization ranging from 5 to $2000 \mathrm{~m} / \mathrm{e}$. Spray chamber temperature was set at $50^{\circ} \mathrm{C}$, and nebulizer gas air pressure was maintained at $35 \mathrm{psi}$. Spray shield temperature was set at \pm 600 volts.

\subsection{IR and ${ }^{13} \mathrm{C}$ NMR Analysis of Fraction $C$}

The IR spectra were recorded as $\mathrm{KBr}$ pellets on the
Bruker spectrophotometer (USA). ${ }^{13} \mathrm{C}$ NMR data were recorded on Bruker Avance II 400 NMR spectrometer (USA) in DMSO, and chemical shifts were expressed in $\delta$ (ppm).

\subsection{Authentication of Isolated Fraction C by HPTLC}

HPTLC analysis was performed on a CAMAG system equipped with high pressure auto sample injector of 100 $\mu \mathrm{l}$ capacity, scanner, UV chamber, and AMAG-Linomat-5 software system for data analysis. Two $\mathrm{mg}$ of cichotyboside was dissolved in $5 \mathrm{ml}$ of methanol and filtered through the Whatman filter paper. Two $\mu l$ of cichotyboside was spotted by auto-injector as a band onto a $10 \times 10 \mathrm{~cm}^{2}$ pre-coated Merck silica gel $60 \mathrm{~F}_{254}$ plates. The plate was run up to a height of $8 \mathrm{~cm}$ in the saturated mobile phase of petroleum ether: benzene: methanol in the ratio of 1:3:2 (v/v). Plates were removed, air dried after development, and finally dried with the aid of drier. The scanning of the plate was performed at $254 \mathrm{~nm}$, and the data was recorded.

\subsection{Assessment of Hepatoprotective Activity of Cichotyboside}

\subsubsection{Test Animals}

Laboratory bred Wistar albino rats of either sex weighing between 150-200 gm were maintained under standard laboratory conditions at $22 \pm 2^{\circ} \mathrm{C}$, relative humidity $60 \pm 5 \%$, and photoperiod of $12 \mathrm{hr}$-dark and light. Commercial pellet diet (Hindustan Lever, India) and water were provided ad-libitum. Animals were not allowed to access water and food before and after $1 \mathrm{hr}$ of dosing. All the experimental interventions were carried out at the same time of day in order to avoid diurnal variation. Institutional Animal Ethics Committee approval was obtained before carrying out animal experiments following the guideline of Committee for the Purpose of Control and Supervision of Experiments on Animals, New Delhi.

\subsubsection{Treatment protocol}

One lower dose of $25 \mathrm{mg} / \mathrm{kg}$ and one higher dose of $100 \mathrm{mg} / \mathrm{kg}$, along with a medium dose of $50 \mathrm{mg} / \mathrm{kg}$, were selected. Animals were randomly divided into six groups, with 12 rats in each. Group I and III-VI were treated as vehicle control (normal saline $0.2 \mathrm{ml} / 100 \mathrm{gm}$, p.o), positive control (silymarin, p.o.), and three different doses of cichotyboside (25, 50 and $100 \mathrm{mg} / \mathrm{kg}$, p.o.) continuously for 14 days. Animals of groups (I-VI) were treated with $\mathrm{CCl}_{4}(1 \mathrm{ml} / \mathrm{kg}$, i.p., of a mixture of $1: 1$ in liquid paraffin) $2 \mathrm{hr}$ after drug treatment on the $7^{\text {th }}$ day, and afterward on alternate days for further 7 days. On the $14^{\text {th }}$ day, $2 \mathrm{hr}$ after drug treatment, 6 animals from each group were used to determine thiopental induced sleeping 
time. The remaining 6 animals from each group were used for biochemical analysis of serum for marker enzymes, BSP clearance, free radical scavenging ability of the liver, and histopathological study of the liver.

Body weights of all the animals were recorded on $1^{\text {st }}$, $7^{\text {th, }}$ and $14^{\text {th }}$ day before sacrifice. The estimation of $\mathrm{CCl}_{4}$ induced prolongation of thiopental sodium $(40 \mathrm{mg} / \mathrm{kg}$, i.p) sleeping time as a measure of liver metabolizing efficiency was done by following the method of Singh et al. [27]. Percentage hepatoprotection in terms of in vitro BSP clearance by liver slices was calculated following the method of Ranjan and Subrahmanyam [28]. Six animals of each group were anesthetized by light ether anesthesia, and blood was withdrawn by the intracardiac puncture. Blood was kept at room temperature to coagulate for 30 $\mathrm{min}$, and serum was separated by centrifugation at 3000 $\mathrm{rpm}$ for $5 \mathrm{~min}$. The serum was used to estimate serum SGOT, SGPT, ALP, cholesterol, high density lipoprotein (HDL), low density lipoprotein (LDL), triglyceride, total and direct bilirubin, protein, and albumin as per the method described in diagnostic kits (Aspen Diagnostic Pvt Ltd., India). The liver, kidney, spleen, and heart were harvested, washed in normal saline, blotted in filter paper, and weighed. Each liver was cut into three portions. Three slices of $60 \mathrm{mg}$ each were cut and weighed from the first part that was used for the BSP clearance test. Liver slices were placed in media $(\mathrm{KCl}: 10 \mathrm{mM}, \mathrm{MgSO} 4: 1 \mathrm{mM}, \mathrm{NaCl}$ : $1 \mathrm{mM}$ in phosphate buffer) containing $30 \mu \mathrm{g} \mathrm{BSP} / \mathrm{ml}$ and incubated at $38^{\circ} \mathrm{C}$. An aliquot of reaction mixture was analyzed after 10, 20 and 30 minutes using spectrophotometer at $580 \mathrm{~nm}$ to determine the BSP concentration in the media [28]. The second part of the liver was used for the estimation of free radical scavenging ability for glutathione [29], lipid peroxidase [30], and superoxide dismutase [31]. The third part of the liver was preserved in a $10 \%$ formalin solution for the histopathological assessment of liver damage. Hematoxylin and eosin staining of liver tissues and the permanent tissue slides were prepared by the following method of Nanji et al. [32].

\subsection{Statistical Analysis}

The results were expressed in terms of Mean \pm SEM. Experimental data were analyzed using one way ANOVA followed by Turkey-Kramer multiple comparisons using the InStat-3 graph pad prism version. Differences between the values of the groups compared were considered significant at $P<0.05$.

\section{Results}

\subsection{Characterization of Cichotyboside}

The isolated fraction $\mathrm{C}$ was obtained as a viscous brown solid mass, which showed a prominent peak having a retention time of 6.906 min (Peak C) in HPLC analysis. LC/MS analysis of fraction $\mathrm{C}$ showed one well defined peak with a retention time of 7.952 min, designated as Peak 1A in LC/MS chromatogram. The Peak 1A showed $\mathrm{m} / \mathrm{z}$ at $472.2\left(\mathrm{M}^{+}\right), 454.5,308.5,280.4,264.7,262.2$, 220.3, 202.7 and 163.3. IR spectrum of fraction C indicated the presence of $-\mathrm{COOH}$ and alcoholic group $\left(3530.73 \mathrm{~cm}^{-1}\right), \gamma$-lactone, ester linkage, and carbonyl group $\left(1654.19 \mathrm{~cm}^{-1}\right)$ and double bond (1574.69 and $\left.714.48 \mathrm{~cm}^{-1}\right)$.

The ${ }^{13} \mathrm{C}$ NMR spectrum of fraction $\mathrm{C}$ exhibited the peaks at $\delta 133.13(\mathrm{C}-1), \delta 196.51(\mathrm{C}-2), \delta 40.27$ (C-3), $\delta$ $136.26(\mathrm{C}-4), \delta 132.20(\mathrm{C}-5), \delta 77.25(\mathrm{C}-6), \delta 39.36$ (C7), $\delta 78.71$ (C-8), $\delta 77.36$ (C- 9), $\delta 141.46$ (C- 10), $\delta 39.57$ (C-11), $\delta 177.89$ (C-12), $\delta 39.78$ (C-13), $\delta 39.99$ (C-14), $\delta$ $127.83\left(\mathrm{C}^{\prime} 1^{\prime}\right), \delta 127.92\left(\mathrm{C}-2^{\prime}\right), \delta 128.02\left(\mathrm{C}-3^{\prime}\right), \delta 128.13$ (C- 4'), $\delta 128.17$ (C- 5'), $\delta 128.22$ (C-6'), $\delta 143.09$ (C- 7'), $\delta 129.08\left(\mathrm{C}-8^{\prime}\right)$ and $\delta 155.46\left(\mathrm{C}-9^{\prime}\right)$. These peaks are well comparable with mass, IR, and ${ }^{13} \mathrm{C}$ NMR data reported by Ahmed et al. and confirm the isolation of cichotyboside. Cichotyboside was further subjected to HPTLC analysis using solvent system petroleum ether: benzene: methanol (1:3:2), which showed the major spot with $R_{f}$ value 0.45 having the area $97.44 \%$ and another spot with $R_{f}$ value 0.72 having the area $2.68 \%$ (Figure 1, 2, 3, 4, 5 and 6). 
Hepatoprotective activity

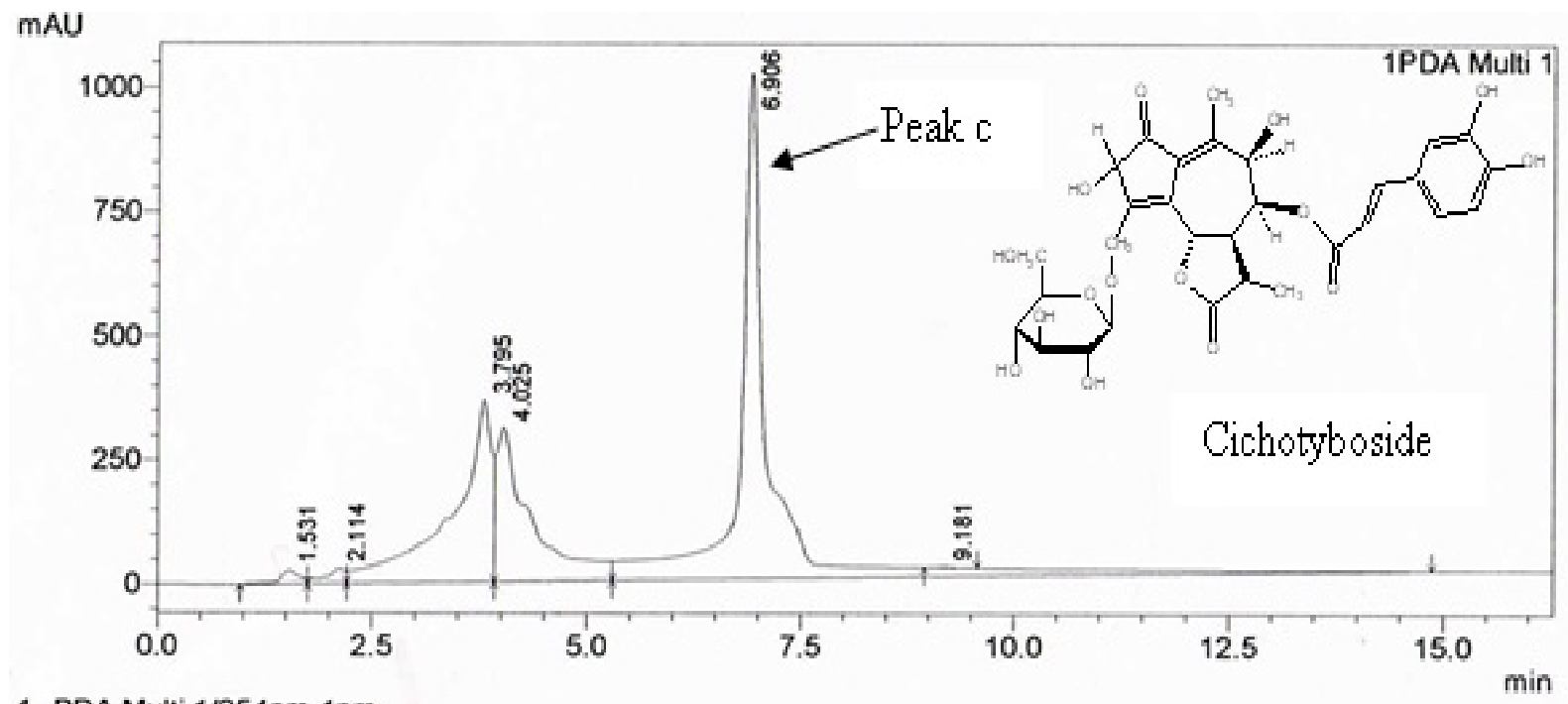

1 PDA Multi $1 / 254 \mathrm{~nm} 4 \mathrm{~nm}$

Peak $\mathrm{C}$ showed retention time at $6.906 \mathrm{~min}$.

Figure 1. HPLC chromatogram of fraction C in mobile phase methanol: water (80:20) scanned at $254 \mathrm{~nm}$. 
MS Data Review All Plots - 9/28/2012 4:34 PM

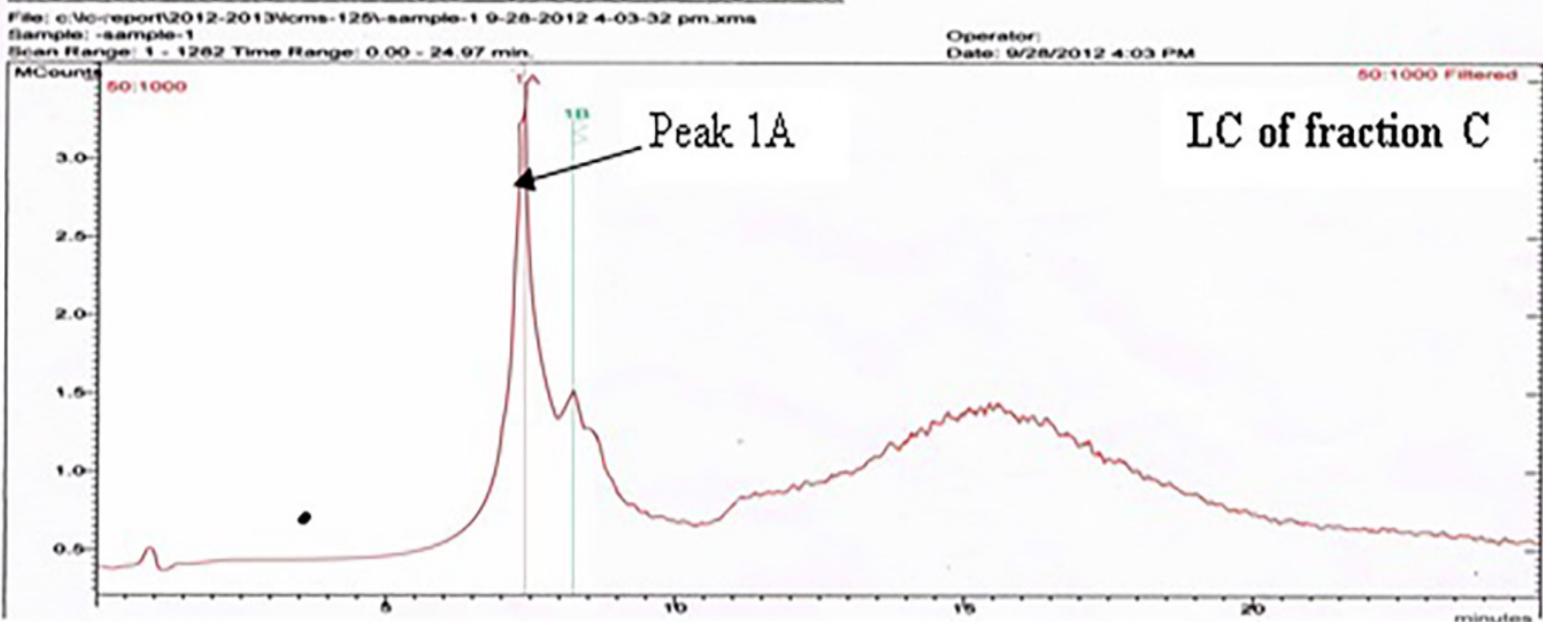

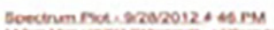

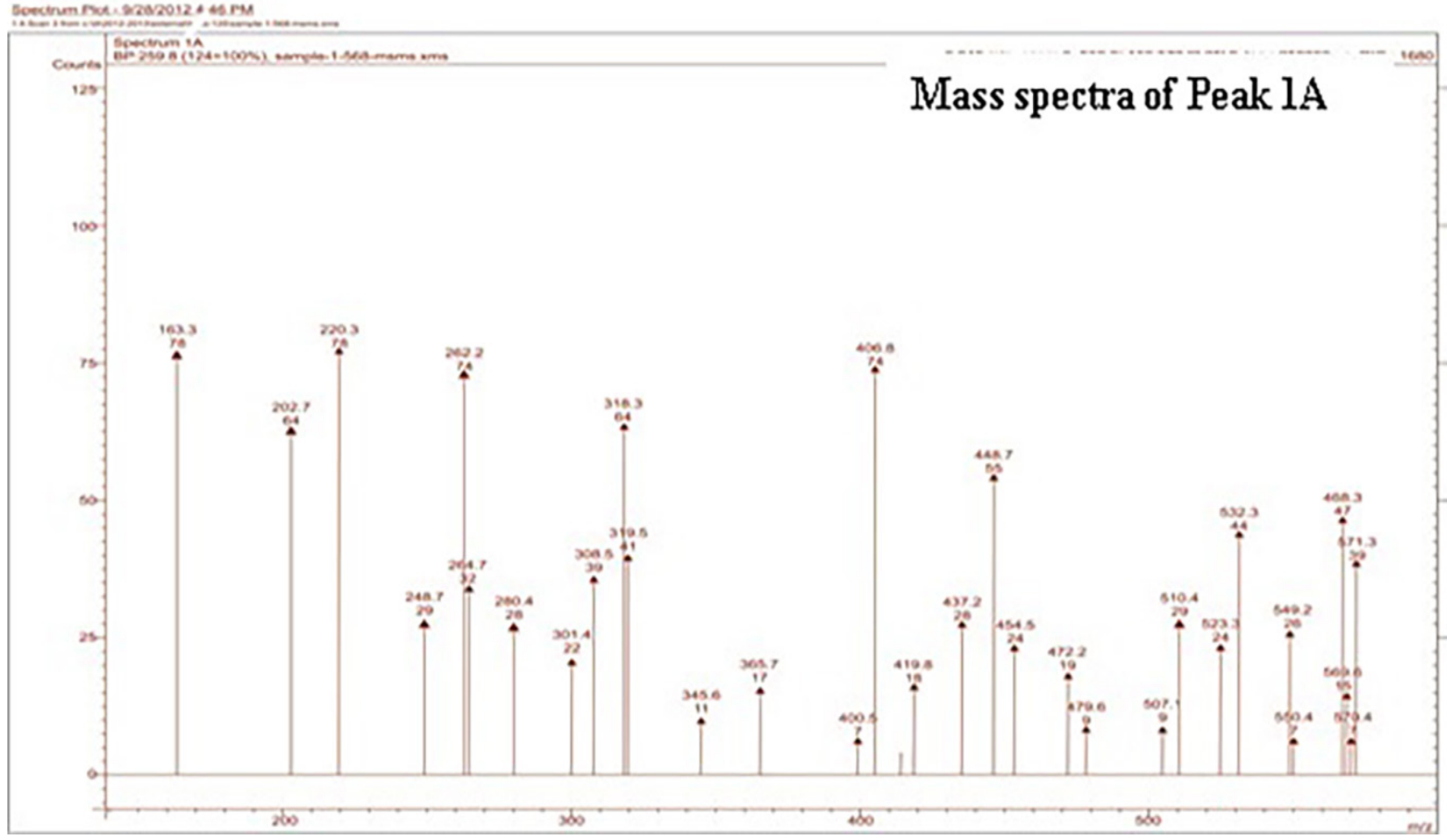

The peak 1A showed $m / z$ at $472.2\left(\mathrm{M}^{+}\right), 454.5,308.5,280.4,264.7,262.2,220.3,202.7$ and 163.3.

Figure 2. LC/MS chromatogram of Fraction C. 


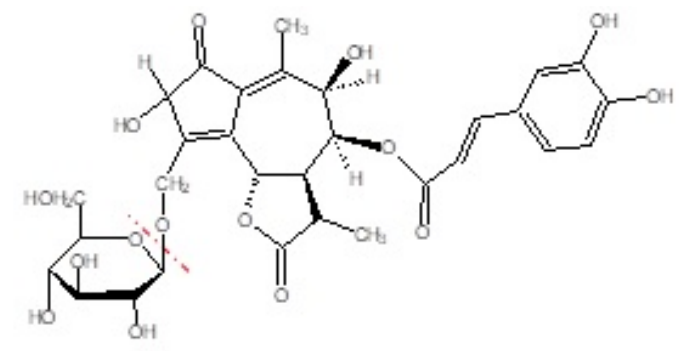

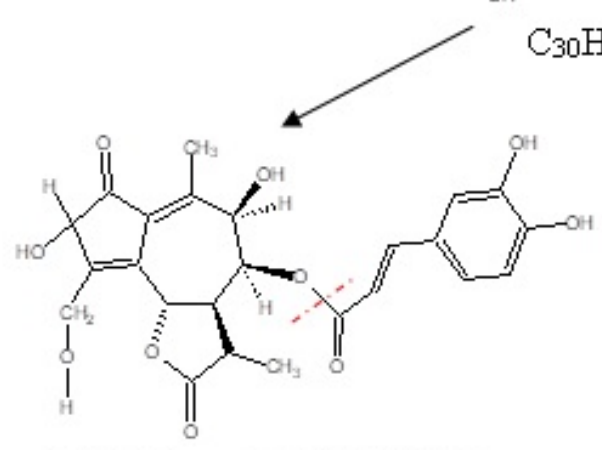

$\mathrm{C}_{24} \mathrm{H}_{24} \mathrm{O}_{10} \quad$ m/e $472(19 \%)$<smiles>CC1=C2C(=O)[C@@H](O)C[C@H]2[C@H]2OC(=O)C=C2C(=O)[C@H]1O</smiles>

$\mathrm{C}_{13} \mathrm{H}_{12} \mathrm{O}_{6} \quad m / z 264.23$ (32\%)

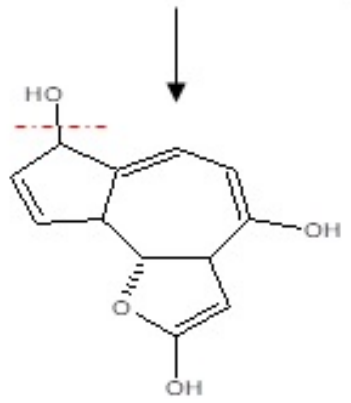

$\mathrm{C}_{12} \mathrm{H}_{12} \mathrm{O}_{4} \quad m / z 220.22(78 \%)$<smiles>O=C/C=C/c1ccc(O)c(O)c1</smiles>

$\mathrm{C}_{9} \mathrm{H}_{7} \mathrm{O}_{3} \quad m / z \quad 163.15$ (78\%)<smiles>CC1=C2C(=O)C(O)C([14CH2]O)=C2[C@@H]2OC(=O)[C@H](C)[C@H]2C(=O)[C@H]1O</smiles>

$\mathrm{C}_{15} \mathrm{H}_{16} \mathrm{O}_{7} \quad m / z 308(39 \%)$<smiles>CC1=C2C(=O)C(O)CC2[C@@H]2OC(=O)[C@H](C(C)(C)C)[C@H]2C(=O)[C@H]1O</smiles>

$\mathrm{C}_{14 \mathrm{H}_{16} \mathrm{O}} \quad m / z 280.27(28 \%)$<smiles>OC1=CC2C(O)=CC=C3CC=CC3[C@@H]2O1</smiles>

$\mathrm{C}_{12} \mathrm{H}_{12} \mathrm{O}_{3}$ $m / z 204.22$ (peak not present in spectra)

Figure 3. Probable fragmentation pattern of fraction $\mathrm{C}$. 


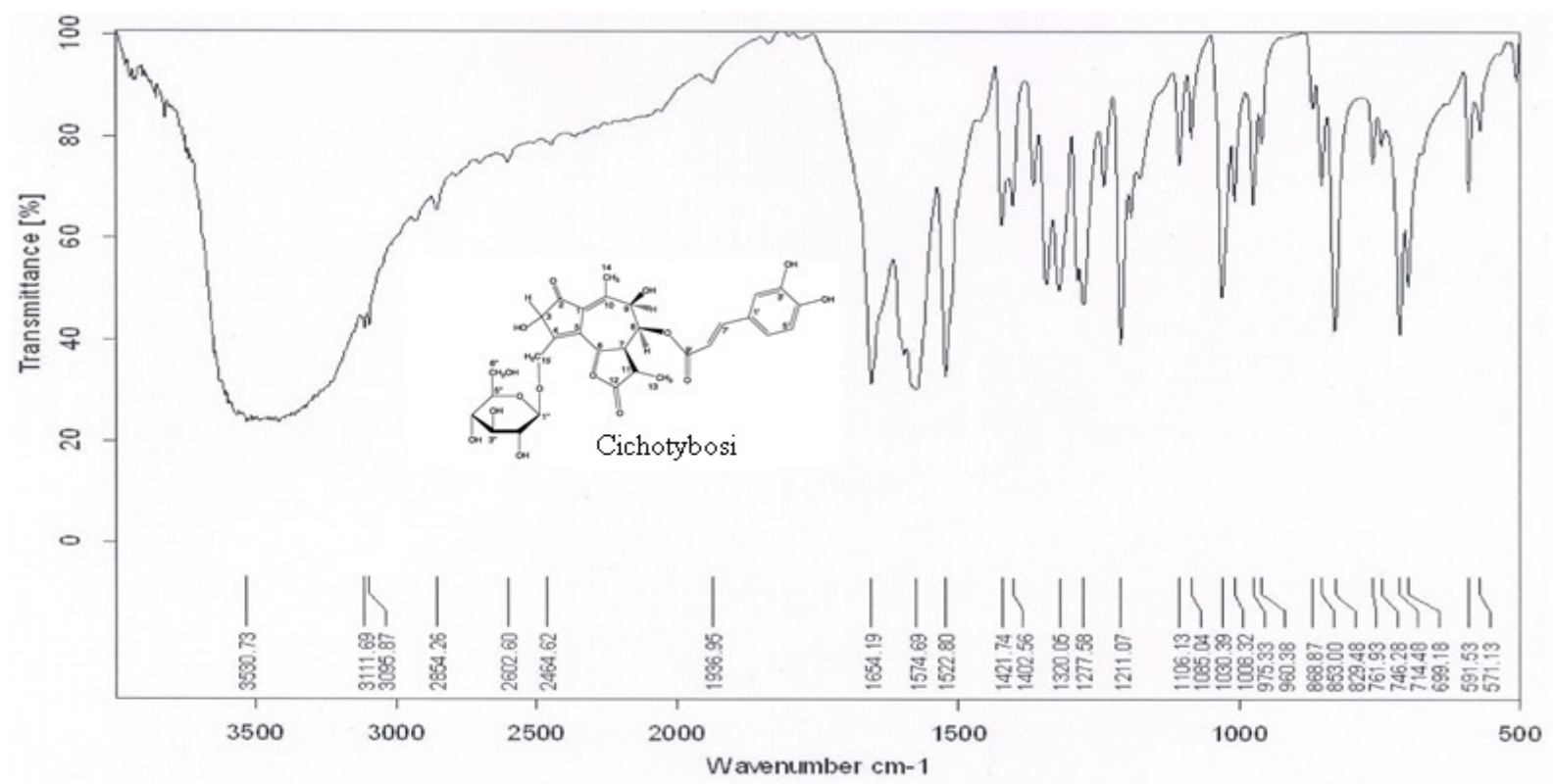

IR spectrum of fraction $\mathrm{C}$ indicated the presence of $-\mathrm{COOH}$ and alcoholic group $\left(3530.73 \mathrm{~cm}^{-1}\right), \gamma$-lactone, ester linkage and carbonyl group (1654.19 $\left.\mathrm{cm}^{-1}\right)$ and double bond $\left(1574.69\right.$ and $\left.714.48 \mathrm{~cm}^{-1}\right)$.

Figure 4. IR spectrum of fraction $C$.

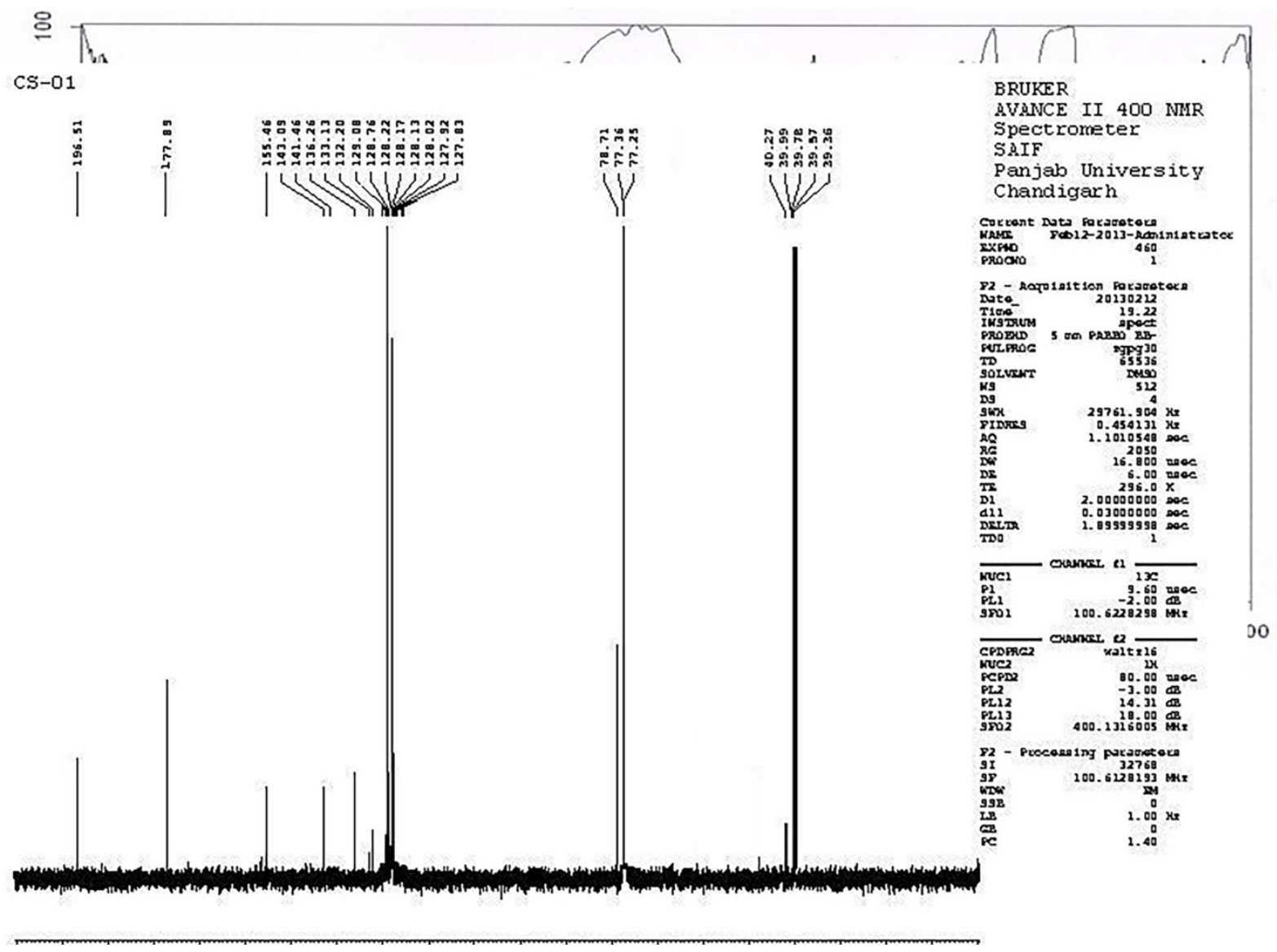

C-2 exhibited the peaks at $\delta 133.13(\mathrm{C}-1), \delta 196.51$ (C- 2), $\delta 40.27$ (C-3), $\delta 136.26(\mathrm{C}-4), \delta 132.20(\mathrm{C}-5), \delta 77.25(\mathrm{C}-6), \delta 39.36(\mathrm{C}-7), \delta 78.71(\mathrm{C}-8), \delta$ 77.36 (C- 9), $\delta 141.46$ (C- 10), $\delta 39.57$ (C-11), $\delta 177.89$ (C-12), $\delta 39.78$ (C-13), $\delta 39.99$ (C-14), $\delta 127.83$ (C-1'), $\delta 127.92$ (C-2'), $\delta 128.02$ (C- 3’), $\delta$ 128.13 (C- 4'), $\delta 128.17$ (C- 5'), $\delta 128.22$ (C-6'), $\delta 143.09$ (C- 7'), $\delta 129.08$ (C-8') and $\delta 155.46$ (C- 9').

Figure 5. ${ }^{13} \mathrm{C}$ NMR spectrum of fraction $\mathrm{C}$. 


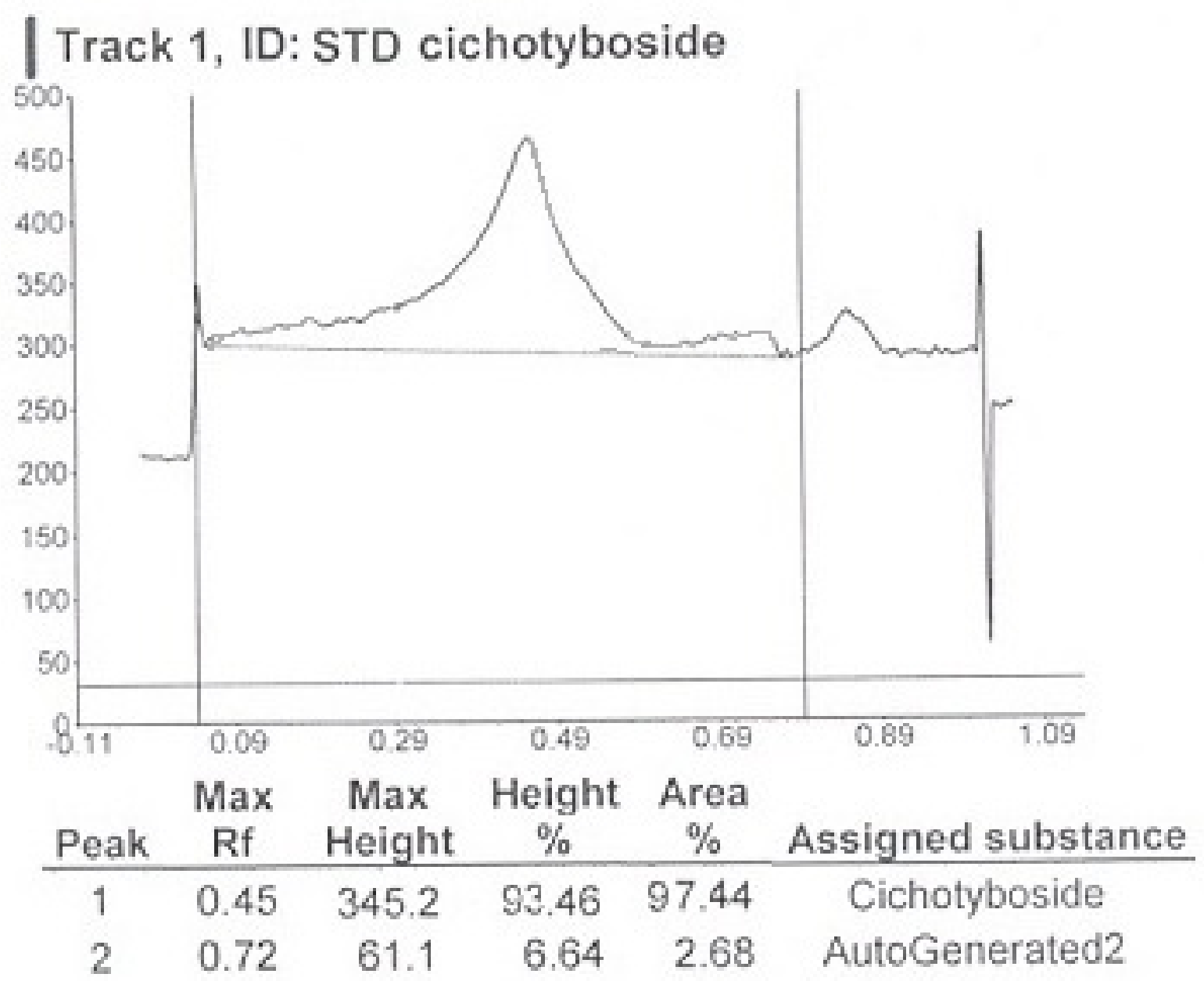

Cichotyboside showed $R_{f} 0.45$ and 0.72 having area percent 97.44 and 2.68 respectively.

Figure 6. HPTLC chromatogram of cichotyboside in solvent system petroleum ether: /benzene: methanol (1:3:2) scanned at $254 \mathrm{~nm}$.

Table 1. Effect of cichotyboside on body weight of $\mathrm{CCl}_{4}$ treated rats

\begin{tabular}{|c|c|c|c|c|c|}
\hline \multirow{2}{*}{ Treatment mg/kg, p.o. } & \multicolumn{3}{|c|}{ Body weight in gm } & \multicolumn{2}{|c|}{$\%$ Change in body weight } \\
\hline & 0 day & $7^{\text {th }}$ day & $14^{\text {th }}$ day & $7^{\text {th }}$ day & $14^{\text {th }}$ day \\
\hline Vehicle control & $176.24 \pm 11.51$ & $183.75 \pm 8.56$ & $188.25 \pm 10.51$ & 4.26 & 6.81 \\
\hline $\mathrm{CCl}_{4}(1 \mathrm{ml} / \mathrm{kg})$ & $191.21 \pm 7.56$ & $196.96 \pm 8.12$ & $181.52 \pm 7.89$ & 3.01 & -5.06 \\
\hline Silymarin (20) & $168.76 \pm 7.55$ & $172.51 \pm 15.05$ & $176.48 \pm 12.45$ & 2.22 & 4.57 \\
\hline Cichotyboside (25) & $154.26 \pm 1.64$ & $157.25 \pm 13.33$ & $149.52 \pm 10.36$ & 1.94 & -3.07 \\
\hline Cichotyboside (50) & $151.51 \pm 1.66$ & $154.52 \pm 10.58$ & $150.50 \pm 11.68$ & 1.98 & -0.66 \\
\hline Cichotyboside (100) & $187.52 \pm 8.66$ & $195.56 \pm 10.40$ & $197.52 \pm 8.81$ & 4.28 & 5.33 \\
\hline
\end{tabular}

Data represented as Mean \pm SEM of 6 animals in each group.

\subsection{Body Weight and Relative Organs Weight}

Post-treatment with silymarin and cichotyboside (100 $\mathrm{mg} / \mathrm{kg}$ ) resulted in body weight gain by 4.57 and $5.33 \%$ in comparison to the decreased body weight $(5.06 \%)$ in $\mathrm{CCl}_{4}$ treated group. Rats administered with $\mathrm{CCl}_{4}$ showed an increase $(3.89 \pm 0.17)$ in relative liver weights, whereas silymarin and cichotyboside (50 and $100 \mathrm{mg} / \mathrm{kg}$ ) revealed significant decrease $(\mathrm{P}<0.05$ and 0.001$)$ in the relative liver weight. Cichotyboside has a non-significant effect on the relative kidney, spleen, and heart weight (Tables 1 and 2).

\subsection{Thiopental Induced Sleeping Time}

Sleeping time $(195.51 \pm 4.95 \mathrm{~min})$ was significantly increased in $\mathrm{CCl}_{4}$ intoxicated rats compared to vehicle control group $(61.26 \pm 2.64 \mathrm{~min})$. Silymarin and 
cichotyboside resulted in an extremely significant decrease $(\mathrm{P}<0.001)$ in thiopental induced sleeping time. The percentage hepatoprotection was $65.67,83.58$, and $88.80 \%$ at 25,50 , and $100 \mathrm{mg} / \mathrm{kg}$ doses of cichotyboside in respect to silymarin $(97.76 \%)$ (Table 3$)$.

\subsection{Bromsulphthalein Uptake by Liver Slices}

Cichotyboside

showed

dose-dependent hepatoprotection of $72.26,80.95$, and $83.33 \%$ respectively after 30 min of incubation whereas, and silymarin showed a hepatoprotection of $86.90 \%$ at $30 \mathrm{~min}$ (Figure 7 ).

Table 2. Effect of cichotyboside on relative organs weight of $\mathrm{CCl}_{4}$ treated rats

\begin{tabular}{|c|c|c|c|c|}
\hline \multirow{2}{*}{ Treatment (mg/kg, p.o.) } & \multicolumn{3}{|c|}{ Organ weight/100 gm of body weight in gm } \\
\cline { 2 - 4 } & Liver & Kidney & Spleen \\
\hline Vehicle control & $3.20 \pm 0.13$ & $0.70 \pm 0.05$ & $0.21 \pm 0.04$ \\
\hline $\mathrm{CCl}_{4}(1 \mathrm{ml} / \mathrm{kg})$ & $3.89 \pm 0.17^{\mathrm{b}}$ & $0.79 \pm 0.05^{\mathrm{ns}}$ & $0.27 \pm 0.05^{\mathrm{ns}}$ & $0.59 \pm 0.08$ \\
\hline Silymarin (20) & $3.28 \pm 0.02^{*, \mathrm{~ns}}$ & $0.68 \pm 0.08^{\mathrm{ns}, \mathrm{ns}}$ & $0.23 \pm 0.01^{\mathrm{ns}, \mathrm{ns}}$ & $0.58 \pm 0.01^{\mathrm{ns}, \mathrm{ns}}$ \\
\hline Cichotyboside (25) & $3.46 \pm 0.12^{\mathrm{ns}, \mathrm{a}}$ & $0.76 \pm 0.04^{\mathrm{ns}, \mathrm{ns}}$ & $0.24 \pm 0.01^{\mathrm{ns}, \mathrm{ns}}$ & $0.65 \pm 0.02^{\mathrm{ns}, \mathrm{ns}}$ \\
\hline Cichotyboside (50) & $3.40 \pm 0.18^{*, \mathrm{a}}$ & $0.73 \pm 0.06^{\mathrm{ns}, \mathrm{ns}}$ & $0.23 \pm 0.03^{\mathrm{ns}, \mathrm{ns}}$ & $0.63 \pm 0.01^{\mathrm{ns}, \mathrm{ns}}$ \\
\hline Cichotyboside (100) & $3.08 \pm 0.14^{* * *, \mathrm{~ns}}$ & $0.71 \pm 0.06^{\mathrm{ns}, \mathrm{ns}}$ & $0.20 \pm 0.07^{\mathrm{ns}, \mathrm{ns}}$ & $0.60 \pm 0.06^{\mathrm{ns}, \mathrm{ns}}$ \\
\hline
\end{tabular}

Data represented as Mean $\pm \mathrm{SEM}$ of 6 animals in each group. ${ }^{*} \mathrm{P}<0.05, * * * \mathrm{P}<0.001$ compared to the negative control $\left(\mathrm{CCl}{ }_{4}\right.$ treated) group. ${ }^{a} \mathrm{P}<0.05$,

${ }^{\mathrm{b}} \mathrm{P}<0.01$ compared to the vehicle control group, and $\mathrm{ns}=$ not significant.

Table 3. Hepatoprotective efficiency of cichotyboside related to restoration of thiopental metabolism associated effect on sleeping time against $\mathrm{CCl}_{4}$ induced liver damage on rats

\begin{tabular}{|c|c|c|}
\hline Treatment (mg/kg, p.o.) & Sleeping time in min & \% Hepatoprotection \\
\hline Vehicle control & $61.26 \pm 2.64$ & - \\
\hline $\mathrm{CCl}_{4}(1 \mathrm{ml} / \mathrm{kg})$ & $195.51 \pm 4.95^{\mathrm{c}}$ & - \\
\hline Silymarin (20) & $64.28 \pm 3.51^{* * *, \mathrm{~ns}}$ & 67.76 \\
\hline Cichotyboside (25) & $107.83 \pm 4.03^{* * * \mathrm{~b}}$ & 65.67 \\
\hline Cichotyboside (50) & $83.65 \pm 5.16^{* * *, \mathrm{~ns}}$ & 83.58 \\
\hline Cichotyboside (100) & $76.39 \pm 4.46^{* * *, \mathrm{~ns}}$ & 88.80 \\
\hline
\end{tabular}

Data represented as Mean $\pm \mathrm{SEM}$ of 6 animals in each group. $* * * \mathrm{P}<0.001$ compared to the negative control $\left(\mathrm{CCl}{ }_{4}\right.$ treated $)$ group. ${ }^{\mathrm{b}} \mathrm{P}<0.01$, ${ }^{c} \mathrm{P}<0.001$ compared to the vehicle control group, and $\mathrm{ns}=$ not significant.

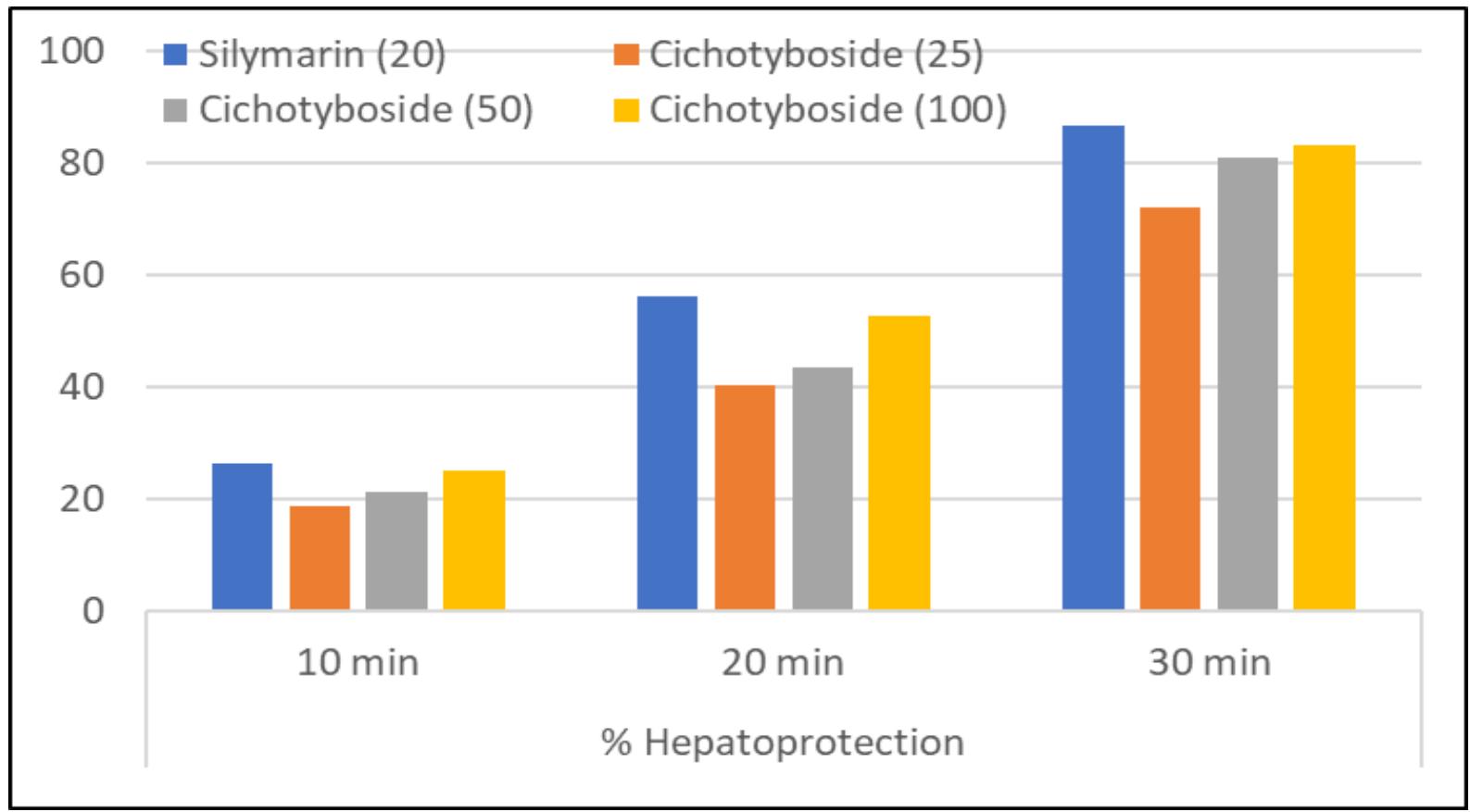

Figure 7. Hepatoprotective effect of cichotyboside on BSP uptake of $\mathrm{CCl}_{4}$ treated rat liver slices. 
Table 4. Hepatoprotective effect of cichotyboside associated serum biochemical parameters of $\mathrm{CCl}_{4}$ treated rats

\begin{tabular}{|c|c|c|c|c|c|c|c|c|c|c|c|}
\hline \multirow{2}{*}{$\begin{array}{c}\text { Treatment } \\
\text { (mg/kg, p.o.) }\end{array}$} & \multirow{2}{*}{$\begin{array}{c}\text { SGOT } \\
\text { IU/I }\end{array}$} & \multirow{2}{*}{$\begin{array}{c}\text { SGPT } \\
\text { IU/I }\end{array}$} & \multirow{2}{*}{ ALP U/I } & \multirow{2}{*}{$\begin{array}{c}\text { Cholesterol } \\
\text { mg/dl }\end{array}$} & \multirow{2}{*}{$\begin{array}{c}\text { Triglyceride } \\
\text { mg/dl }\end{array}$} & \multirow{2}{*}{$\begin{array}{l}\text { HDL } \\
\mathrm{mg} / \mathrm{dl}\end{array}$} & \multirow{2}{*}{$\begin{array}{l}\text { LDL } \\
\mathrm{mg} / \mathrm{dl}\end{array}$} & \multicolumn{2}{|c|}{ Bilirubin mg/dl } & \multirow{2}{*}{$\begin{array}{c}\text { Protein } \\
\text { gm/dl }\end{array}$} & \multirow{2}{*}{$\begin{array}{c}\text { Albumin } \\
\text { gm/dl }\end{array}$} \\
\hline & & & & & & & & Total & Direct & & \\
\hline Vehicle control & $\begin{array}{c}46.38 \pm \\
2.78 \\
\end{array}$ & $\begin{array}{c}39.08 \pm \\
2.54 \\
\end{array}$ & $\begin{array}{c}47.26 \pm \\
2.18 \\
\end{array}$ & $\begin{array}{c}126.33 \pm \\
5.46 \\
\end{array}$ & $\begin{array}{c}126.49 \pm \\
7.24 \\
\end{array}$ & $\begin{array}{c}47.55 \pm \\
3.39 \\
\end{array}$ & $\begin{array}{c}53.48 \pm \\
3.29 \\
\end{array}$ & $\begin{array}{c}1.52 \pm \\
0.07 \\
\end{array}$ & $\begin{array}{c}0.63 \pm \\
0.02 \\
\end{array}$ & $\begin{array}{c}6.80 \pm \\
0.33 \\
\end{array}$ & $\begin{array}{c}4.97 \pm \\
0.21 \\
\end{array}$ \\
\hline $\mathrm{CCl}_{4}(1 \mathrm{ml} / \mathrm{kg})$ & $\begin{array}{c}92.65 \pm \\
5.01^{\mathrm{c}} \\
\end{array}$ & $\begin{array}{c}104.81 \pm \\
6.51^{\mathrm{c}} \\
\end{array}$ & $\begin{array}{c}132.65 \pm \\
6.98^{\mathrm{c}} \\
\end{array}$ & $\begin{array}{c}189.63 \pm \\
10.65^{\mathrm{c}} \\
\end{array}$ & $\begin{array}{c}261.16 \pm \\
5.86^{\mathrm{c}} \\
\end{array}$ & $\begin{array}{c}22.64 \pm \\
2.09^{\mathrm{c}} \\
\end{array}$ & $\begin{array}{c}114.75 \pm \\
5.98^{\mathrm{c}} \\
\end{array}$ & $\begin{array}{c}2.12 \pm \\
0.12^{\mathrm{a}} \\
\end{array}$ & $\begin{array}{c}2.06 \pm \\
0.26^{\mathrm{c}} \\
\end{array}$ & $\begin{array}{c}4.86 \pm \\
0.17^{\mathrm{b}} \\
\end{array}$ & $\begin{array}{c}3.68 \pm \\
0.11^{\mathrm{a}} \\
\end{array}$ \\
\hline Silymarin (20) & $\begin{array}{l}40.88 \pm \\
2.14^{* * *, n s}\end{array}$ & $\begin{array}{c}53.63 \pm \\
3.37^{* * *, n s}\end{array}$ & $\begin{array}{l}49.11 \pm \\
6.16^{* * *, n s}\end{array}$ & $\begin{array}{c}134.56 \pm \\
6.03^{* *, n s}\end{array}$ & $\begin{array}{l}178.56 \pm \\
4.98^{* * *, n s}\end{array}$ & $\begin{array}{l}48.59 \pm \\
2.12^{* * *, n s}\end{array}$ & $\begin{array}{c}50.25 \pm \\
2.19^{* * *, n s}\end{array}$ & $\begin{array}{c}1.56 \pm \\
0.12^{\mathrm{ns}, \mathrm{ns}} \\
\end{array}$ & $\begin{array}{c}0.96 \pm \\
0.01^{* * *, n s}\end{array}$ & $\begin{array}{l}6.04 \pm \\
0.25^{*, \text { ns }}\end{array}$ & $\begin{array}{l}4.39 \pm \\
0.15^{*, \text { ns }}\end{array}$ \\
\hline Cichotyboside (25) & $\begin{array}{l}48.63 \pm \\
5.02^{* *, n s}\end{array}$ & $\begin{array}{l}49.50 \pm \\
2.91^{* * *, n s}\end{array}$ & $\begin{array}{l}86.73 \pm \\
2.78^{* * *, a} \\
\end{array}$ & $\begin{array}{c}159.33 \pm \\
8.67^{\mathrm{ns}, \mathrm{a}}\end{array}$ & $\begin{array}{c}197.36 \pm \\
4.98^{* * *, a} \\
\end{array}$ & $\begin{array}{l}32.67 \pm \\
2.19^{\text {ns,a }} \\
\end{array}$ & $\begin{array}{l}87.19 \pm \\
4.52^{* * *, a} \\
\end{array}$ & $\begin{array}{l}2.06 \pm \\
0.11^{\mathrm{ns}, \mathrm{a}} \\
\end{array}$ & $\begin{array}{c}1.09 \pm \\
0.05^{* * *, \mathrm{a}} \\
\end{array}$ & $\begin{array}{l}5.97 \pm \\
0.16^{*, a}\end{array}$ & $\begin{array}{l}3.92 \pm \\
0.12^{\text {ns,a }}\end{array}$ \\
\hline Cichotyboside (50) & $\begin{array}{c}40.36 \pm \\
3.54^{* * *, n s}\end{array}$ & $\begin{array}{l}44.96 \pm \\
5.45^{* * *, n s} \\
\end{array}$ & $\begin{array}{l}73.58 \pm \\
6.95^{* * *, a} \\
\end{array}$ & $\begin{array}{c}151.61 \pm \\
11.74^{*} \text {,ns } \\
\end{array}$ & $\begin{array}{r}183.47 \pm \\
8.93^{* * *,}, \mathrm{a} \\
\end{array}$ & $\begin{array}{l}35.42 \pm \\
3.17^{*, \text { ns }} \\
\end{array}$ & $\begin{array}{r}79.49 \pm \\
4.28^{* * *, n s} \\
\end{array}$ & $\begin{array}{l}1.93 \pm \\
0.33^{\text {ns,a }} \\
\end{array}$ & $\begin{array}{c}1.05 \pm \\
0.03^{* * *, a} \\
\end{array}$ & $\begin{array}{c}6.14 \pm \\
0.23^{* *, \mathrm{~ns}}\end{array}$ & $\begin{array}{l}4.16 \pm \\
0.13^{\text {ns,a }} \\
\end{array}$ \\
\hline Cichotyboside (100) & $\begin{array}{c}38.19 \pm \\
3.80^{* * *, n s}\end{array}$ & $\begin{array}{c}41.65 \pm \\
4.86^{* * *, n s}\end{array}$ & $\begin{array}{c}59.34 \pm \\
2.44^{* * *, n s}\end{array}$ & $\begin{array}{l}143.95 \pm \\
6.90^{* *, n s} \\
\end{array}$ & $\begin{array}{l}169.66 \pm \\
7.58^{* * *}, \mathrm{~ns} \\
\end{array}$ & $\begin{array}{c}42.56 \pm \\
3.64^{* * *, n s}\end{array}$ & $\begin{array}{c}67.45 \pm \\
4.15^{* * *, n s} \\
\end{array}$ & $\begin{array}{c}1.87 \pm \\
0.09^{\mathrm{ns,a}} \\
\end{array}$ & $\begin{array}{c}0.82 \pm \\
0.14^{* * *, n s}\end{array}$ & $\begin{array}{c}6.23 \pm \\
0.27^{* *, \mathrm{~ns}} \\
\end{array}$ & $\begin{array}{c}4.27 \pm \\
0.13^{\text {ns,ns }} \\
\end{array}$ \\
\hline
\end{tabular}

Data represented as Mean \pm SEM of 6 animals in each group. ${ }^{*} \mathrm{P}<0.05,{ }^{*} \mathrm{P}<0.01,{ }^{* * *} \mathrm{P}<0.001$ compared to the negative control (CCl $\mathrm{C}_{4}$ treated) group. ${ }^{\text {a }} \mathrm{P}<0.05,{ }^{\mathrm{b}} \mathrm{P}<0.01,{ }^{\mathrm{c}} \mathrm{P}<0.001$ compared to the vehicle control group, and ns $=$ not significant. 
Table 5. Effect of cichotyboside on free radical scavenging ability of $\mathrm{CCl}_{4}$ treated rat liver

\begin{tabular}{|c|c|c|c|}
\hline $\begin{array}{c}\text { Treatment } \\
(\mathbf{m g} / \mathbf{k g}, \mathbf{p . o} .)\end{array}$ & $\begin{array}{c}\text { Glutathione } \boldsymbol{\mu g} / \mathbf{g m} \text { of } \\
\text { liver }\end{array}$ & $\begin{array}{c}\text { Lipid peroxidase nmol/gm of } \\
\text { protein }\end{array}$ & $\begin{array}{c}\text { Superoxide dismutase Unit/mg } \\
\text { of protein }\end{array}$ \\
\hline Vehicle control & $21.05 \pm 1.83$ & $3.88 \pm 0.71$ & $6.24 \pm 0.76$ \\
\hline $\mathrm{CCl}_{4}(1 \mathrm{ml} / \mathrm{kg})$ & $5.61 \pm 0.69^{\mathrm{c}}$ & $21.38 \pm 1.69^{\mathrm{c}}$ & $3.13 \pm 0.59^{\mathrm{a}}$ \\
\hline Silymarin (20) & $19.61 \pm 1.57^{* * *, \mathrm{~ns}}$ & $4.65 \pm 0.58^{* * *, \mathrm{~ns}}$ & $6.06 \pm 0.71^{*, \mathrm{~ns}}$ \\
\hline Cichotyboside (25) & $8.30 \pm 0.71^{\mathrm{ns}, \mathrm{c}}$ & $4.38 \pm 0.77^{* * *, \mathrm{~ns}}$ & $3.33 \pm 0.58^{\mathrm{ns}, \mathrm{a}}$ \\
\hline Cichotyboside (50) & $11.18 \pm 0.97^{*, \mathrm{a}}$ & $4.32 \pm 0.64^{* * *, \mathrm{~ns}}$ & $4.56 \pm 0.62^{\mathrm{ns,a}}$ \\
\hline Cichotyboside (100) & $14.32 \pm 1.23^{* * *, \mathrm{~ns}}$ & $4.12 \pm 0.64^{* * *, \mathrm{~ns}}$ & $5.59 \pm 0.48^{*, \mathrm{~ns}}$ \\
\hline
\end{tabular}

Data represented as Mean $\pm \mathrm{SEM}$ of 6 animals in each group. $* \mathrm{P}<0.05, * * * \mathrm{P}<0.001$ compared to the negative control $\left(\mathrm{CCl} \mathrm{C}_{4}\right.$ treated $)$ group. ${ }^{\mathrm{a}} \mathrm{P}<0.05,{ }^{\mathrm{c}} \mathrm{P}<0.001$ compared to the vehicle control group, and $\mathrm{ns}=$ not significant.

\subsection{Serum Biochemical Parameters}

The outcome of biochemical parameters revealed a severe increase in the levels of SGOT, SGPT, ALP, cholesterol, triglyceride, LDL, total and direct bilirubin in plasma. In contrast, the level of HDL, protein, and albumin was decreased considerably in $\mathrm{CCl}_{4}$ intoxicated animals. Cichotyboside dose-dependently showed a significant decrease $(\mathrm{P}<0.01$ to 0.001$)$ in serum SGOT, SGPT, ALP, triglyceride, LDL, and cholesterol level, whereas, serum HDL and protein level was significantly increased $(\mathrm{P}<0.05$ and 0.001). Cichotyboside has a non-significant effect on the normalization of total bilirubin while showed a highly significant decrease $(\mathrm{P}<0.001)$ in direct bilirubin (Table 4).

\subsection{Free Radical Scavenging Ability of Liver}

Treatment with cichotyboside showed a significant increase $(\mathrm{P}<0.05-0.001)$ in glutathione and superoxide dismutase levels compared to the decreased level in the $\mathrm{CCl}_{4}$ group. Cichotyboside dose-dependently caused an extremely significant decrease $(\mathrm{P}<0.001)$ in the liver lipid peroxidase level (Table 5).

\subsection{Histopathology}

Histopathological assessment of hematoxylin-eosin stained liver sections showed a concentrically arranged normal hepatocytes around the central vein and portal tracts in the vehicle control rat liver tissue. $\mathrm{CCl}_{4}$ intoxicated liver hepatocytes showed neutrophilic infiltration, sinusoidal dilatation, zonal necrosis, vacuolar degeneration, and microvesicular fatty changes. Liver tissue of silymarin treated group showed a small area of focal necrosis and slightly altered hepatic parenchyma. Cichotyboside $(100 \mathrm{mg} / \mathrm{kg})$ treatment showed sinusoidal dilatation, very little focal coagulative necrosis, and nearly normalized hepatocytes (Figure 8a-f). 

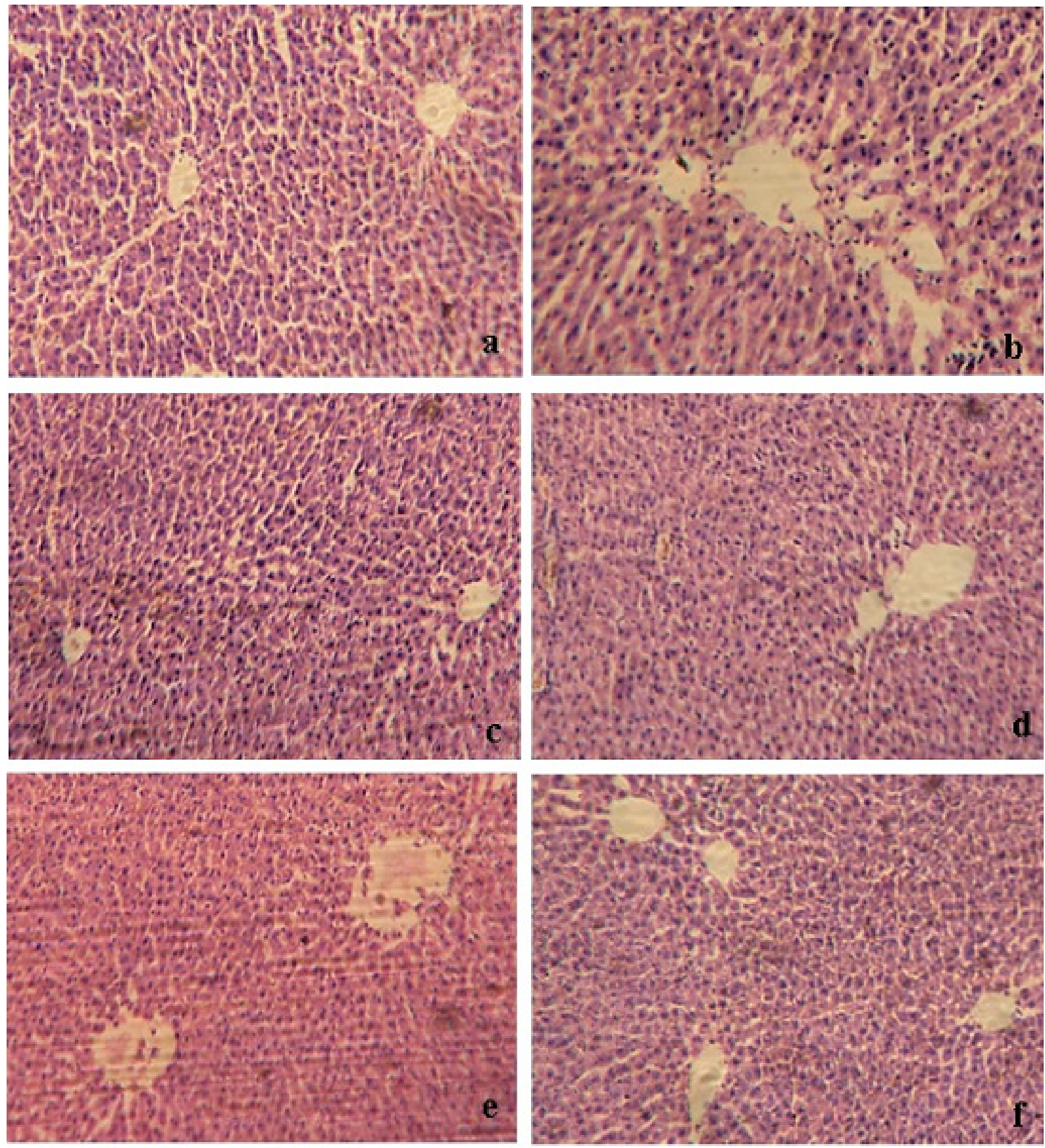

Figure 8. Assessment of $\mathrm{CCl}_{4}$ induced hepatotoxicity by histopathology in haematoxylin-eosin stained liver sections.

(a) The liver of control animal showed normal cellular architecture with distinct hepatocyte; (b) $\mathrm{CCl}_{4}$ intoxicated liver tissue showed neutrophilic infiltration, sinusoidal dilatation, zonal necrosis, extensive diffuse vacuolar degeneration engorged with blood and microvesicular fatty changes in hepatocytes; (c) Silymarin treated liver tissue showed small area of focal necrosis and slightly altered hepatic parenchyma; (d) Cichotyboside (25 mg/kg) pretreatment showed coagulative, lobular and centrilobular necrosis along with sinusoidal dilatation; (e) Cichotyboside (50 mg/kg) pretreatment showed focal coagulative necrosis, sinusoidal dilatation and altered hepatic parenchyma; (f) Cichotyboside (100 $\mathrm{mg} / \mathrm{kg}$ ) pretreatment showed sinusoidal dilatation, very little focal coagulative necrosis with nearly normalized hepatocytes.

\section{Discussion}

C. intybus is a traditionally well-acclaimed hepatoprotective plant having usability in treating liver damage. Whole plant, leaf, root, and seeds extracts have been scientifically explored for hepatoprotection. Leaves are reported to contain hepatoprotective phytoconstituents esculetin and chicoric acid [33]. Esculetin is reported to reduce oxidative stress by decreasing liver cell swelling, necrosis and leukocyte infiltration $[34,35]$. Ahmed et al. isolated cichotyboside from $C$. intybus seeds, and reported hepatoprotective activity by estimating SGOT, SGPT, and ALP only following $\mathrm{CCl}_{4}$ induced hepatotoxicity on rats 
[26]. This study attempts the isolation of the promising hepatoprotective bioactive compound cichotyboside from C. intybus seeds and standardization by spectral analysis and further characterization by HPLC and HPTLC. This study is the first to report HPLC and HPTLC characterization of cichotyboside for future identification and reference standard purposes, which will help in the identification and also for reference standard purposes. This study attempts to evaluate the effect of cichotyboside on liver damage reversibility, antioxidant potential, metabolic functionality, and histopathology.

$\mathrm{CCl}_{4}$ induced hepatotoxicity is an authentic experimental model to evaluate hepatoprotective agents. The cytochrome $\mathrm{P}_{450}$ system biotransforms $\mathrm{CCl}_{4}$ to an active hepatotoxic metabolite, trichloromethyl radical. Trichloromethyl radical covalently binds to the cell protein, starting a chain of reactions eventually leading to cell and endoplasmic reticulum membrane lipid peroxidation. Lipid peroxidation leads to the generation of malondialdehyde that damages the cytoplasmic membrane. The peroxidative products cause hypoperfusion of the membrane, resulting in the escape of cytosolic enzymes in the blood [36]. A significant loss of body weight was observed in the negative control group compared to the control group accompanied with reduced food consumption. An increase in liver weight is common in the case of $\mathrm{CCl}_{4}$ intoxication due to fatty changes [37].

Cichotyboside treatment showed a significant reversal towards the dose-dependent gain of body weight and relative liver weight suggesting normalization of $\mathrm{CCl}_{4}$ toxicity towards the regeneration of hepatocytes. The liver plays a pivotal role in the metabolism and elimination of substances from the portal circulation by two distinct pathways via cytochrome p-450 and GSH-peroxidase. Animals with intoxicated liver show prolonged sleeping duration while treated with barbiturates due to damage of hepatic microsomal drug metabolizing enzymes. Thiopental induced sleeping time increases as the enzyme responsible for its metabolism is reduced in liver damage [38]. Cichotyboside showed a protective effect, as evidenced by decrease in sleeping duration, indicating restoration of barbiturate metabolizing capacity may be through modulation of hepatic biotransformation. Cichotyboside at all three doses has significantly improved the BSP clearance capacity of the damaged liver, maintaining phase II drug metabolism capacity, enabling to excrete the dye and, in turn, signifying less damage to the hepatic cells.

Hepatotoxin $\mathrm{CCl}_{4}$ gets converted into $\mathrm{CCl}_{3} \mathrm{O}^{-}$by liver enzymes that attack the unsaturated fatty acids of the cell membrane. This consequently gives rise to lipid peroxidation altering the functional integrity of hepatocyte mitochondria and, ultimately, liver damage. Toxicants disbalances synthesis and metabolism of triglycerides, cholesterol, and lipoproteins by damaging the hepatocytes. The serum liver function marker enzymes like SGOT,
SGPT, and ALP levels are elevated [36]. Serum triglyceride and bilirubin (total and direct) levels elevated, whereas serum HDL, total protein, and albumin levels decreased. The increased triglyceride content in the blood indicates fatty degeneration of the liver. Two prime manifestations of liver failure are the deposition of triglycerides leading to fatty liver and disturbance in cholesterol synthesis rate that occurs following disturbance in lipid metabolism. These are common manifestations of chronic alcoholism featuring disordered hepatic lipid metabolism. Ahmed et al. reported that 50 $\mathrm{mg} / \mathrm{kg}$ (p.o.) dose of cichotyboside is relatively safe and showed maximum hepatoprotective effect against $\mathrm{CCl}_{4}$ induced hepatotoxicity in Wistar albino rats [26]. Based on the three dose 25,50 and $100 \mathrm{mg} / \mathrm{kg}$ was evaluated in vivo. Cichotyboside treatment showed a near normal level of liver marker enzymes exhibiting hepatoprotective effect. This decrease may be due to cichotyboside induced enhancement in cell integrity and, as a consequence, reduced leakage of enzymes into the bloodstream.

Cichotyboside treatment demonstrated a considerable reduction in serum triglyceride and cholesterol levels indicating normalization of synthesis rate. Interference of hepatic bilirubin uptake can produce a mild unconjugated hyperbilirubinemia [39]. Liver cell injury impedes hepatic uptake of unconjugated bilirubin resulting in Hyperbilirubinemia [40]. Cichotyboside treatment has significantly reduced the total and direct bilirubin levels in serum. Reduced serum total proteins level in the $\mathrm{CCl}_{4}$ treated rats directly correlates with hepatopathy severity. Hypoalbuminemia is mostly associated with advanced chronic liver diseases, which is correlated with the severity of cellular dysfunction. Cichotyboside normalizes the serum protein concentration of $\mathrm{CCl}_{4}$ intoxicated rats, demonstrating a beneficial response on cellular macromolecule regeneration.

Hepatocytes are defended from oxidative damage by non-enzymatic and enzymatic systems like glutathione peroxidase, superoxide dismutase, and catalase. Oxidative stress induces an imbalance in the formation and removal of free radicals giving rise to the production of reactive oxygen species like superoxide, hydrogen peroxide, and hydroxyl radicals. In severe oxidative stress, these oxidative compounds interact with cellular lipid, protein, DNA, and plasma membrane leading to pathological implications. Lipid peroxidation is considered one of the major biochemical hallmarks of $\mathrm{CCl}_{4}$-induced hepatotoxicity. An increase in glutathione activity in cichotyboside treated groups indicated the restoration of vital molecules and reversal of peroxidative damage.

The whole herb, leaf, seed, and root of C. intybus is being reported to have hepatoprotective potential earlier $[12,22,23]$. Phytoconstituents like Esculetin and cichoric acid is also reported for potential protective effect against paracetamol, CCl4 and anti-hepatitis B virus induced hepatic damage [24,25]. Cichotyboside is the most 
promising phytocompound [26] which surely needed further evaluation. Comprehensive hepatoprotective assessment of cichotyboside in this study reveals its multifaceted beneficial effect as a protective from oxidative stress induced hepatocyte damage. Cichotyboside showed a significant reduction in lipid peroxidation, indicating its antioxidant activity further supported by the restoration of superoxide dismutase in the liver. Cichotyboside may have maintained cellular defense mechanisms by preventing cell membrane oxidation. Cichotyboside treatment reversed neutrophilic infiltration, necrosis, vacuolar degeneration, and fatty changes in hepatocytes. Hepatoprotective activity of cichotyboside can be attributed to the preservation of hepatocyte membrane structural integrity by protecting from breakage by the reactive metabolites. Plants containing sesquiterpene glycoside constituents are reported to have hepatoprotective activity against D-galactosamine, $\mathrm{CCl}_{4}$, and acute immunological liver injury [41-43].

\section{Conclusion}

The mass, IR, and ${ }^{13} \mathrm{C}$ NMR data confirms the isolation of cichotyboside compared to previous report. This is first report of cichotyboside LC/MS with a well-defined peak that showed mass fragmentation pattern signifying breakdown of cichotyboside. All the study parameter outcome substantiates hepatoprotective potential of cichotyboside against $\mathrm{CCl}_{4}$-induced liver damage. Hepatoprotective activity of cichotyboside may be due to its sesquiterpene glycoside structure, which prevents hepatocyte plasma membrane alteration and promote repair. Histopathological evaluation revealed that cichotyboside reduced oxidative stress in rat liver characterized by decreased fatty changes, leukocyte infiltration, and necrosis. Cichotyboside plays a preventative role in free radical generated hepatotoxicity by reversing metabolic functionality and cell damage. This study provided new insights into the mechanism of the hepatoprotective effect of cichotyboside from $C$. intybus, A well reputed plant used for the treatment of liver disease. The developed HPLC and HPTLC methods can be used for the quality control analysis of $C$. intybus and can also be explored for the pharmacokinetic and pharmacodynamic analysis in the future.

\section{Acknowledgements}

The authors are thankful to State Drug testing Laboratory, Food and Drugs Administration, Govt. of Madhya Pradesh, Bhopal for providing the HPTLC analysis facility.

\section{Declaration of Competing Interest}

The authors have no conflicts to declare.

\section{REFERENCES}

[1] Rastogi RP., BN. Mehrotra, Compendium of Indian medicinal plants, Madras, Orient Longman Ltd, 1994, pp. 74 .

[2] Afzal S., Afzal N., Awan MR., Khan TS., Khanum AG., S. Tariq, Ethno-botanical studies from Northern Pakistan. Journal of Ayub Medical College Abbottabad, vol. 21, no. 1, 502-557, 2009. https://pubmed.ncbi.nlm.nih.gov/20364741 /

[3] Reddy BS., Hamid R., CV. Rao, Effect of dietary oligofructose and inulin on colonic preneoplastic aberrant crypt foci inhibition, Carcinogenesis, vol. 18, no. 7, 1371-1374, 1997. DOI: 10.1093/carcin/18.7.1371.

[4] Aqil F., I. Ahmad, Broad-spectrum antibacterial and antifungal properties of certain traditionally used Indian medicinal plants. World Journal of Microbiology and Biotechnology, vol. 19, 653-657, 2003. DOI: 10.1023/A:1025128104056.

[5] Mehrotra R., Katiyar CK., AP. Gupta, Hepatoprotective compositions and composition for treatment of conditions related to hepatitis $\mathrm{B}$ and $\mathrm{E}$ infection, US Patent no. 6136316, Washington DC. USA, Patent and Trademark Office, 1997.http://www.freepatentsonline.com/6136316.h tml.cited on 4/01/2009

[6] HM. Said, Diseases of the liver: Greco-Arab Concepts, Pakistan, Hamdard Foundation Press, 1982, pp. 80-85.

[7] Street RA., Sidana J., G. Prinsloo, Cichorium intybus: Traditional uses, phytochemistry, pharmacology, and toxicology, Evidence-Based Complementary and Alternative Medicine, vol. 579319, 2013. DOI: $10.1155 / 2013 / 579319$.

[8] Madani H., Talebolhosseini M., Asgary S., GH. Nader, Hepatoprotective activity of Silybum marianum and Cichorium intybus against thioacetamide in rat, Pakistan Journal of Nutrition, vol. 7, 172-176, 2008. DOI: 10.3923/pjn.2008.172.176.

[9] Abbasi AM., Khan MA., Ahmad M., Zafar M., Khan H., Muhammad N., et al., Medicinal plants used for the treatment of jaundice and hepatitis based on socio-economic documentation. African Journal of Biotechnology, vol. 8, no. 8, 1643-1650, 2009. DOI: 10.5897/AJB2009.000-9243.

[10] Gilani AH., Janbaz KH., MH. Javed Hepatoprotective activity of Cichorium intybus, an indigenous medicinal plant, Medical Science Research, vol. 21, 151-152, 1993.

[11] Helal EGE., Abd El-Wahab S., Sharaf AMM., G. Zedan, Effect of Cichorium intybus L. on fatty liver induced by oxytetracycline in albino rats, The Egyptian Journal of Hospital Medicine, vol. 45, 522-535, 2011. DOI: 10.12816/ejhm.2011.16381. 
[12] Atta AH., Elkoly TA., Mouneir SM., Kamel G., Alwabel NA., S. Zaher, Hepatoprotective effect of methanol extracts of Zingiber officinale and Cichorium intybus, Indian Journal of Pharmaceutical Sciences, vol. 72, no. 5, 564-570, 2010. DOI: 10.4103/0250-474X.78521.

[13] Gadgoli C., SH. Mishra Antihepatotoxic activity of Cichorium intybus. Journal of Ethnopharmacology, vol. 58, no. 2, 131-134, 1997. DOI: 10.1016/s0378-8741(03)00145 -4 .

[14] Elgengaihi S., Mossa AH., Refaie AA., D. Aboubaker, Hepatoprotective Efficacy of Cichorium intybus L. extract against carbon tetrachloride-induced liver damage in rats, Journal of Dietary Supplements, vol. 13, no. 5, 570-584, 2016. DOI: 10.3109/19390211.2016.1144230.

[15] Heibatollah S., Reza NM., Izadpanah G., S. Sohailla, Hepatoprotective effect of Cichorium intybus on $\mathrm{CCl}_{4}$ induced liver damage in rats, African Journal of Biochemistry Research, vol. 2, no. 6, 141-144, 2008. DOI: 10.5897/AJBR.9000130

[16] Mushtaq A., Ahmad M., Q. Jabeen, Pharmacological role of Cichorium intybus as a hepatoprotective agent on the elevated serum marker enzymes level in albino rats intoxicated with nimesulide, International Journal of Current Pharmaceutical Research, vol. 5, no. 3, 25-30, 2013.

[17] Gilani AH., KH. Janbaz. Evaluation of the liver protective potential of Cichorium intybus seed extract on Acetaminophen and $\mathrm{CCl}_{4}$-induced damage, Phytomedicine, vol. 1, no. 3, 193-197, 1994. DOI: 10.1016/S0944-7113(11 )80064-4.

[18] Ahmed B., Al-Howiriny TA., AB. Siddiqui, Antihepatotoxic activity of seeds of Cichorium intybus, Journal of Ethnopharmacology, vol. 7, no. 2-3, 237-240, 2003. DOI: $10.1016 / \mathrm{s} 0378-8741(03) 00145-4$.

[19] Zafar R., SM. Ali, Anti-hepatotoxic effects of root and root callus extracts of Cichorium intybus L, Journal of Ethnopharmacology, vol. 63, no. 3, 227-231, 1998. DOI: 10.1016/s0378-8741(98)00087-7.

[20] Krylova SG., Efimova LA., Vymiatina ZK., EP. Zueva, The effect of cichorium root extract on the morphofunctional state of liver in rats with carbon tetrachloride induced hepatitis model, Eksperimental'naia i klinicheskaia farmakologiia, vol. 69, no. 6, 34-36, 2006. https://pubmed.ncbi.nlm.nih.gov/17209462/

[21] Fallah HH., Mahmoudabady AZ., Ziai SA., Mehrazma M., Alavian SM., Mehdizadeh M., et al., The effects of Cynara scolymus L. leaf and Cichorium intybus L. root extracts on carbon tetrachloride induced liver toxicity in rats, Journal of Medicinal Plant, vol. 10, no. 37, 33-40, 2011. DOI: 10.1186/s40064-016-1894-1.

[22] Molan AL., Duncan AJ., Barry TN., WC. McNabb, Effect of condensed tannins and sesquiterpene lactones extracted from chicory on the motility of larvae of deer lungworm and gastrointestinal nematodes, Parasitology International, vol. 52, no. 2, 209-218, 2003. DOI: 10.1016/S1383-5769(03)00 011-4.

[23] Nandagopal S., BD. Ranjitha kumara, Phytochemical and antibacterial studies of Chicory (Cichorium intybus L.) - A multipurpose medicinal plant, Advances in Biological
Research, vol. 1, no. 1-2, 17-21, 2007. https://citeseerx.ist.psu.edu/viewdoc/download?doi=10.1.1 $.588 .3047 \&$ rep $=$ rep $1 \&$ type $=$ pdf

[24] Gilani AH., Janbaz KH., BH. Shah, Esculetin prevents liver damage induced by paracetamol and $\mathrm{CCL}_{4}$, Pharmacological Research, vol. 37, no. 1, 31-35, 1998. DOI: 10.1006/phrs.1997.0262.

[25] Zhang HL., Dai LH., Wu YH., Zhang HL., Dai LH., Wu YH., et al., Evaluation of hepatocyteprotective and anti-hepatitis B virus properties of Cichoric acid from Cichorium intybus leaves in cell culture, Biological and Pharmaceutical Bulletin, vol. 37, no. 7, 1214-1220, 2014. DOI: $10.1248 / \mathrm{bpb} . b 14-00137$.

[26] Ahmed B., Khan S., Masood MH., AH. Siddique, Anti-hepatotoxic activity of cichotyboside, a sesquiterpene glycoside from the seeds of Cichorium intybus, Journal of Asian Natural Product Research, vol. 10, no. 3-4, 223-231, 2008. DOI: $10.1080 / 10286020701590764$.

[27] Singh B., Saxena AK., Chandan BK., Agrawal SG., KK. Anand, In vivo hepatoprotective activity of active fraction from ethanolic extract of Eclipta alba leaves, Indian Journal of Physiology and Pharmacology, vol. 45, no. 4, 435-441, 2001. https://pubmed.ncbi.nlm.nih.gov/11883149/

[28] Ranjan R., K. Subrahmanyam, Uptake of sodium phenol tetrabromosulphalein (bromosulphalein) by rat liver slices under different conditions, Indian Journal of Experimental Biology, vol. 3, 100-103, 1965. https://pubmed.ncbi.nlm.ni h.gov/14338048/

[29] F. Tietze, Enzymic method for quantitative determination of nanogram amounts of total and oxidized glutathione: Applications to mammalian blood and other tissues, Analytical Biochemistry, vol. 27, no. 3, 502-522, 1969. DOI: $10.1016 / 0003-2697(69) 90064-5$.

[30] Ohkawa H., Ohishi N., K. Yagi, Assay for lipid peroxides in animal tissues by thiobarbituric acid reaction. Analytical Biochemistry, vol. 95, no. 2, 351-358, 1979. DOI: 10.1016/0003-2697(79)90738-3.

[31] Misra HP., I. Fridovich, The role of superoxide anion in the autoxidation of epinephrine and simple assay for superoxide dismutase, Journal of Biological Chemistry, vol. 247, no. 10, 3170-3175, 1972. https://pubmed.ncbi.nlm.nih .gov/4623845/

[32] Nanji AA., Jokelainen K., Fotouhinia M., Rahemtulla A., Thomas P., Tipoe GL., et al., Dannenberg AJ. Increased severity of alcoholic liver injury in female rats: Role of oxidative stress, endotoxin, and chemokines, The American Journal of Physiology-Gastrointestinal and Liver Physiology, vol. 281, no. 6, G1348-G1356, 2002. DOI: 10.1152/ajpgi.2001.281.6.G1348.

[33] Bais HP., GA. Ravishankar, Cichorium intybus L. cultivation, processing, utility, value addition and biotechnology, with an emphasis on current status and future prospects, The Journal of the Science of Food and Agriculture, vol. 81, no. 5, 467-484, 2001. DOI: $10.1002 /$ jsfa. 817 .

[34] Lee MJ., Chou FP., Tseng TH., Hsieh MH., Lin MC., CJ. Wang, Hibiscus protocatechuic acid or esculetin can inhibit oxidative LDL induced by either copper ion or nitric oxide donor, Journal of Agricultural and Food Chemistry, vol. 50. 
2130-2136, 2002. DOI: 10.1021/jf011296a.

[35] Choi RY., Ham JR., MK. Lee, Esculetin prevents non-alcoholic fatty liver in diabetic mice fed high-fat diet, Chemico-Biological Interactions, vol. 260, 13-21, 2016. DOI: 10.1016/j.cbi.2016.10.013.

[36] Gergely J., Kulcsar A., J. Harsfalvi, Changes in fat metabolism in acute carbon tetrachloride intoxication of rats, Acta Pharmaceutica Hungarica, vol. 65, no. 1, 3-4, 1995. https://pubmed.ncbi.nlm.nih.gov/7725927/

[37] NM. Abdel-Hamid, Diphenyl dimethyl bicarboxylate as an effective treatment for chemical-induced fatty liver in rat, African Journal of Biomedical Research, vol. 9, 77-81, 2006. DOI: 10.4314/ajbr.v9i2.48778.

[38] Singh B., Saxena AK., Chandan BK., Bhardwaj V., Gupta VN., Suri OP., et al., Hepatoprotective activity of indigtone - A bioactive fraction from Indigofera tinctoria Linn, Phytotherapy Research, vol. 15, no. 4, 294-297, 2001. DOI: 10.1002/ptr.760.

[39] Rubin E., JL. Farber, Essential pathology. 3rd ed,
Philadelphia, Lippincott Williams and Wilkins, 2001, pp. 393.

[40] Recknagel RO., Glende JEA., Dolak JA., RL. Waller, Mechanism of carbon tetrachloride toxicity, Pharmacology and Therapeutics, vol. 43, no. 1, 139-145, 1989. DOI: 10.1016/0163-7258(89)90050-8

[41] Li Y., Chen Z., Feng Z., Yang Y., Jiang J., P. Zhang, Hepatoprotective glycosides from Leonurus japonicus Houtt, Carbohydrate Research, vol. 348, 42-46, 2012. DOI: 10.1016/j.carres.2011.10.034.

[42] Li Y., Zhang DM., Li JB., Yu SS., Li Y., YM. Luo, Hepatoprotective sesquiterpene glycosides from Sarcandra glabra, Journal of Natural Product, vol. 69, no. 4, 616-620, 2006. DOI: $10.1021 / \mathrm{np050480d.}$

[43] Yang WJ., Luo YQ., Aisa HA., Xin XL., Totahon Z., Mao Y., et al., Hepatoprotective activities of a sesquiterpene-rich fraction from the aerial part of Cichorium glandulosum, Chinese Medicine, vol. 7, no. 1, 21, 2012. DOI: 10.1186/1749-8546-7-21. 